DOI: $10.2478 /$ ausae-2021-0010

\title{
The role of municipalities and landscape architects in the public involvement processes related to green infrastructure developments
}

\section{Andrea KERESZTES-SIPOS,, ${ }^{1}$ Anita REITH, ${ }^{2}$ Albert FEKETE, ${ }^{3}$ Péter I. BALOGH ${ }^{4}$}

Institute of Landscape Architecture, Urban Planning and Garden Art, Hungarian

University of Agriculture and Life Sciences (MATE), Budapest, Hungary

${ }^{1}$ Department of Garden Art and Garden Design; e-mail: keresztessiposandrea@gmail.com

${ }^{2}$ Department of Garden and Open Space Design; e-mail: reithanita88@gmail.com

${ }^{3}$ Department of Garden Art and Garden Design; e-mail: Fekete.Albert@uni-mate.hu

${ }^{4}$ Department of Garden and Open Space Design; e-mail: Balogh.Peter.Istvan@uni-mate.hu

Manuscript received 10 August 2021; revised 25 September 2021; accepted 09 October 2021

\begin{abstract}
While urban green infrastructure has a great importance with regard to the urban climate, human welfare and well-being due to the positive impact of ecosystem services, it also offers opportunities to practice democracy. The quality of a green infrastructure development process depends on the quality of the partnership between the many stakeholders. Municipalities have a permanent task and a role to play in building partnerships. Landscape architects often go beyond their engineering tasks to give priority to their professional vocations in public involvement processes. In our research, we examine the roles and responsibilities of these main stakeholder groups.
\end{abstract}

Keywords: inclusive municipality, community planning tool, democracy, engagement experts, participation

\section{Introduction}

The ecosystem services of the urban green infrastructure (UGI) not only have an outstanding role in reducing the unpleasant effects of the urban climate [1] but also can significantly increase the quality of human welfare and well-being, which makes the UGI a highly important element of the urban fabric and city life [2, 3].

"The landscape belongs to everyone. We should all have equal access to it and a voice in how it is used, valued and maintained." - this is the mission statement of the European collaboration between landscape architecture faculties called 
Landscape Education for Democracy (LED) [4] that aims to highlight the importance to use democratic processes for UGI developments. The right to landscape and to UGI is part of the basic human rights that support existence and dignity [5]. The public landscape is not only a set of physical elements and resources but is also an imprint of the social, economic, and cultural values of the local community, and therefore it is the spatial materialization of democracy [6].

Due to the fact that many stakeholders - such as local authorities, landscape architects, and other engineers, investors, social workers, contractors, users, etc. - can be identified who in some way play a role in developing or maintaining the UGI, the latter has a combination of ecological, social, and also economic importance. The collaboration of the many stakeholder groups is essential to any UGI development process, and a strong partnership in place is a key factor of the overall success of the development process. That is why UGI developments are great opportunities to practise democracy [6].

By nature, municipalities have a significant role in building and maintaining partnerships and public involvement ${ }^{1}$ [7], wherefore their deep engagement in UGI developments is essential. There are many examples of strong partnerships within the local community that increase the chances of successful investments and make maintenance more efficient [8].

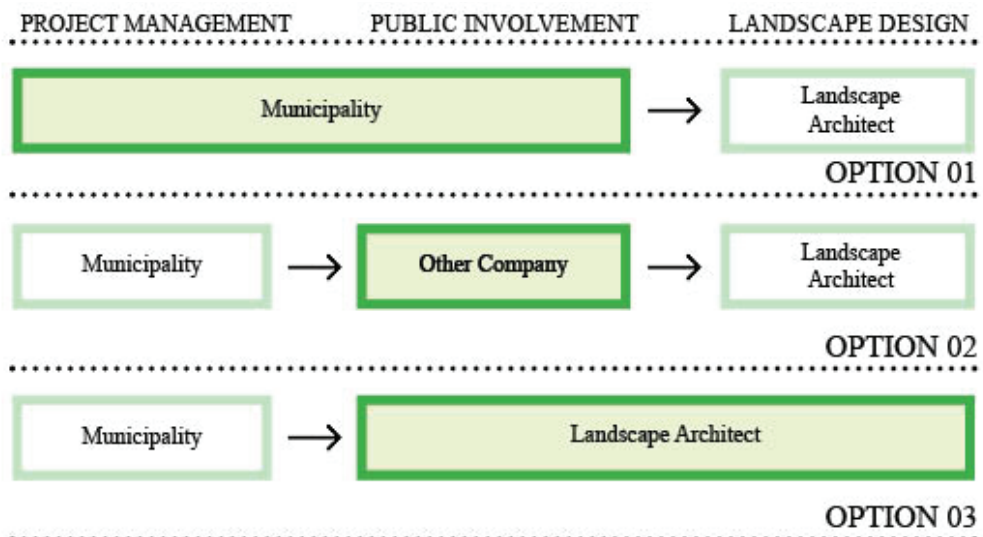

Figure 1. Roles in the public involvement process

1 In our research, we use the term "public involvement" to refer to any means that gives members of the local community the opportunity to have a say and participate in shaping the development of the city (e.g. posters, forums). Involvement is a more specific form of participatory planning, of which community planning is a concrete instrument [21]. 
In Hungary, it is very common that the municipality is the actor who initiates participation processes for UGI developments because of their existing relationships and partnerships with the local stakeholders. In practice, there are three different routes that we can observe [9]:

- municipality takes the leading role and implements public involvement with its own employees,

- makes a contract with a company to lead the public involvement process, and - the (landscape) designer undertakes this extra task besides their general role.

In this research, we examine the first and second option to discover their advantages and disadvantages (Figure 1, where the darker box shows the leader of the involvement process). Our research looks into the roles and responsibilities of the landscape architect and the municipality and also outlines the main characteristics of their relationship.

\section{Materials and methods}

The research is divided into two units: in the first part, we examine the actors of the public involvement, and in the second part we present the theories through two case studies.

The study is based on a review of the related literature, and the results are presented in tables. The case study projects and an interview with a specialist in community planning and local government processes helped to bring the topic down to a practical level.

In selecting the projects for the case study, it was important that they be part of the TÉR_KÖZ programme we were looking at, the main aim of which was to ensure that projects were initiated by local communities, or at least involve local residents, in order to enable more sustainable use and greater acceptance of community spaces and to contribute to the reinforcement of local communities. The TÉR_KÖZ programme was announced by the Municipality of Budapest, and district municipalities could apply with project plans. Between 2013 and 2018, a total of 90 projects worth HUF 90 billion were implemented [10].

\section{Results and discussions}

The KÖFOP-2.3.4-VEKOP-15-2016-00002 - Monitoring Local Government Development II, a comprehensive study of municipalities in Hungary, was completed in 2018, which confirmed the hypothesis that there was a correlation between greater public involvement and the success of municipalities [11]. One of the most important characteristics of inclusive municipalities ${ }^{2}-$ which is a key

2 "An inclusive municipality is a municipality that implements a mechanism for dialogue between local authorities, local organizations, businesses, and the public in order to achieve innovative 
objective - is how often they involve the population in the preparation of certain decisions. The results suggest that municipalities with larger populations rely more intensively on public opinion than those with smaller ones [13].

It was also found that both informal and formal methods play an important role in terms of involvement, but this is also determined by the size of the settlements. In smaller communities, face-to-face, day-to-day contact in the absence of formal mechanisms can lead to a high level of inclusiveness, while in larger settlements the role of formal processes is much more important. However, informal channels can also operate either between different groups of residents and stakeholders or between opinion leaders and local communities - neighbourhoods [14].

This means that it is in the interest of local authorities to adopt the practice of public involvement, and in the case of larger cities such as Budapest, it is definitely worth relying on formal procedures, which are multi-actor processes.

\section{A. Actors}

The key players in the public involvement process can be identified as the relevant municipal leaders, the professionally involved municipal experts, the planners who are awarded the planning task, and the facilitator who leads the involvement. The key actors will carry out the stakeholder analysis in the first phase of the involvement process in order to identify the large number of stakeholders who will be concerned and who should be included in the project $[15,16]$.

As stated in an earlier paper of ours, there is a wide range of actors who, based on their profession, play an important role in the public involvement process [17] (Table 1). In practice, however, it can be observed that this wide range of experts is not involved, and the whole project is carried out by a smaller group of experts in three different formations (Figure 1). In our analysis, we will examine the role of landscape architects in public involvement, covering also the possibilities for local municipalities.

Landscape architects play an important role in public involvement related to UGI development, as they are the designers and often the facilitators as well. In his doctoral thesis, Tamás Dömötör distinguishes eight types of landscape architect design roles for social engagement, which imply different competences in each design phase (Table 1). Dömötör concludes that the design roles are required in addition to the basic design competences in the facilitator role, and their

and sustainable operation and development, based on democratic principles, involving in the process the widest possible range of stakeholders, taking into account their expectations and the empowerment of marginalized groups. It manages community resources competently and develops and implements local strategies and services in partnership, while promoting inclusive development and poverty reduction. It supports the development and involvement of communities to mobilize social capital, thus contributing to improving local governance and territorial cohesion" ([12] - translated by the authors). 
existence is not self-evident as they also depend on certain personal aptitudes and qualifications.

Table 1: Characteristics of design roles (own ed.) $[17,18]$

\begin{tabular}{|l|c|c|c|c|c|c|c|}
\hline $\begin{array}{l}\text { Design roles/ } \\
\text { Areas of competence }\end{array}$ & Expert & Connection & $\mathbf{A}^{\mathbf{3}}$ & $\mathbf{B 1}^{4}$ & $\mathbf{B 2}^{5}$ & $\mathbf{C}^{6}$ & $\mathbf{D}^{7}$ \\
\hline $\begin{array}{l}\text { Advisor - objectivity, } \\
\text { professional authority }\end{array}$ & c., d., f., g., l. & ID & & $\mathrm{X}$ & $\mathrm{X}$ & & \\
\hline $\begin{array}{l}\text { Mediator - empathy, conflict } \\
\text { management skills, good } \\
\text { communication skills }\end{array}$ & a., c., k. & ID & & (X) & $\mathrm{X}$ & & \\
\hline $\begin{array}{l}\text { Spokesperson, or advocate } \\
\text { good communication and } \\
\text { reasoning skills }\end{array}$ & a., c., h. & (LD), GD & (X) & $\mathrm{X}$ & $\mathrm{X}$ & & \\
\hline $\begin{array}{l}\text { Assessor - knowledge of } \\
\text { presentation techniques, } \\
\text { good presentation skills, } \\
\text { persuasiveness, decisiveness }\end{array}$ & a., c. & ID & $\mathrm{X}$ & $\mathrm{X}$ & $\mathrm{X}$ & & \\
\hline $\begin{array}{l}\text { Facilitator - knowledge } \\
\text { of social psychology (e.g. } \\
\text { group dynamics), good } \\
\text { communication skills }\end{array}$ & a., b., c., k. & ID, (LD), & $\mathrm{X}$ & $\mathrm{X}$ & (X) & & \\
\hline $\begin{array}{l}\text { Community organizer - } \\
\text { good communication skills, } \\
\text { organizational skills }\end{array}$ & b., c., (h.), k. & LD, GD & $\mathrm{X}$ & $\mathrm{X}$ & (X) & $\mathrm{X}$ & \\
\hline $\begin{array}{l}\text { Administrator - systematic } \\
\text { thinking, computer skills, } \\
\text { organizational skills }\end{array}$ & $\begin{array}{c}\text { (a.), (b.), c., d., } \\
\text { e., j. }\end{array}$ & (ID), LD & $\mathrm{X}$ & $\mathrm{X}$ & (X) & (X) & (X) \\
\hline $\begin{array}{l}\text { Landscape steward - } \\
\text { perseverance, leadership skills }\end{array}$ & c., & LD, GD, L & $\mathrm{X}$ & $\mathrm{X}$ & $\mathrm{X}$ & $\mathrm{X}$ & $\mathrm{X}$ \\
\hline
\end{tabular}

Notes: ${ }^{1}$ Engagement experts: a. Communication expert; b. Community developer; c. Landscape architect; d. Project manager; e. Graphic designer; f. Contractor; g. Lawyer; h. Politician; i. Artist; j. Filmmaker; k. Social worker; l. Expert on the special subjects. ${ }^{2}$ Relationship of the landscape architect: ID - independent, LD - location-related, GD group-related, L - local. ${ }^{3}$ The birth of the project. ${ }^{4}$ Planning. ${ }^{5}$ Planning - Plan consultation. ${ }^{6}$ Implementation. ${ }^{7}$ Afterlife.

Since Dömötör's dissertation in 2008, public involvement has become a more widely known method in Hungary, and a great deal of practical experience has been accumulated. It was then that the process of landscape architects taking on the tasks of many other professions began, and they had to continue their education to meet the challenges. However, this extra work cannot be undertaken by any designer because public involvement is not for everyone, as it requires a well-communicating, empathetic, calm character and attitude, which is not 
an essential prerequisite for a good designer's personality [9]; not to mention the fact that one cannot fulfil all the planning roles at the same time because an independent consultant cannot be a member of the local community or a facilitator of the process (Table 1).

The idea seems to emerge that landscape architect designers are not required to take on the roles presented in Table 1 but that all designers need a general knowledge of involvement (e.g. knowledge of the community design processes, presentation skills, etc.) and that, in addition, specialization is possible as required. Some designers may have the basic skills and goals to lead the public involvement process, but others may not, or may be more interested in spending more time on landscape architecture design. In this case, since most of the facilitator landscape architect design roles can be decomposed into other disciplines, the tasks not strictly related to the profession can be delegated in whole or in part to other professionals, as shown in Table 1, where the engaged experts and design roles are mapped.

Újirány Landscape Architects Ltd has also organized several community design projects for municipalities, including one of our research case studies, the community design of Holdudvar Park. It was formulated that the public involvement tasks involved in public outreach required so much effort that there was little time for planning, so they were happy to work with a team of community developers and communication specialists from District III of Budapest [9].

Municipalities can play a major role in taking on these tasks because they can bring together all the players and coordinate the work either on their own or with the help of engagement experts. Another argument in favour of municipalities and local experts is that a comprehensive study of municipalities in Hungary, KÖFOP-2.3.4-VEKOP-15-2016-00002 - Monitoring Municipal Developments II, found that the strength of local identity and the involvement of local expertise in decision making is positively correlated with the success of a municipality [14].

\section{B. Case studies - Two projects of the TÉR_KÖZ programme}

We would like to use the case studies to demonstrate the operation of the first and second options in Figure 1, and thus two different landscape architectural and self-government roles can be seen.

Both projects were funded by the Municipality of Budapest in the TÉR_KÖZ programme in 2016, both are located in the District III of Budapest, and both were coordinated by the same team, Óbuda-Békásmegyer Urban Development Ltd (ÓBUD Ltd), owned by the municipality - so, the difference in landscape architecture is easier to understand. The staff of ÓBUD Ltd, which was in charge of the development tasks, includes several experts necessary for the involvement: community developer, 
communication specialist, graphic designer, project manager, landscape architect, and jurist.

Blessed Sándor István Park has an area of $8,350 \mathrm{~m}^{2}$, of which $4,700 \mathrm{~m}^{2}$ are green spaces. Despite its small size, it has several functions: play and sports areas, a dog run, and a recreation area [19].

Public involvement was carried out through a variety of tools and in all phases of the project, one of the most important elements being the on-site community planning, which took place in three sessions in the autumn of 2015. The deteriorated park was initially intended by the municipality to be a sports park, but feedback from residents led to its transformation into a multifunctional recreational space [9].

The whole process was managed by ÓBUD Ltd, where the designer had no participatory role but had to attend the meetings and shape the design according to what had been discussed.

Holdudvar Park covers an area of 23,000 $\mathrm{m}^{2}$, of which 12,000 $\mathrm{m}^{2}$ are green spaces. It is a huge and multifunctional green space located between the high-rises of the Bécsi and Vörösvári streets in Óbuda residential area. The project took a year to complete and ultimately enriched the area with a slide park, a teenager's leisure area, sports areas, playgrounds, community space, and a stage.

Public involvement was done through a very wide and varied range of tools, covering all project phases, except the birth of the project phase. The planning phase was fully carried out by a contracted landscape architectural firm, the Újirány Landscape Architects Ltd, the key element of which was a nine-part community planning activity [20]. Subsequently, in the implementation and afterlife phases, the involvement tasks were taken over by the municipality's ÓBUD Ltd [9].

Table 2. Public involvement tools and tasks of the landscape architect and the municipality in the two case studies (own ed.) [9, 17]

\begin{tabular}{|c|c|c|c|c|c|c|c|c|c|c|c|}
\hline \multirow{2}{*}{$\begin{array}{l}\text { Success factors } \\
\text { for public } \\
\text { involvement }\end{array}$} & \multirow[t]{2}{*}{$\begin{array}{l}\text { Expert: } \\
\text { LA }^{1}\end{array}$} & \multicolumn{5}{|c|}{$\begin{array}{c}\text { Establishment of Blessed } \\
\text { Sándor István Park } \\
\end{array}$} & \multicolumn{5}{|c|}{$\begin{array}{c}\text { Revitalization of Holdudvar } \\
\text { Park }\end{array}$} \\
\hline & & $\mathrm{A}^{2}$ & $\mathbf{B}^{3}$ & $\mathrm{C}^{4}$ & $\overline{D^{5}}$ & $M / \mathbf{L A}^{6}$ & $A^{2}$ & $\mathbf{B}^{3}$ & $\mathrm{C}^{4}$ & $D^{5}$ & $\mathbf{M} / \mathbf{L A}^{6}$ \\
\hline \multicolumn{12}{|l|}{ Public } \\
\hline Flyer, newsletter & & $\mathrm{X}$ & & $\mathrm{X}$ & $\mathrm{X}$ & $\mathrm{M}$ & & $\mathrm{X}$ & $\mathrm{X}$ & & M, LA \\
\hline Posters, billboards & & & & $\mathrm{X}$ & $\mathrm{X}$ & $\mathrm{M}$ & & $\mathrm{X}$ & $\mathrm{X}$ & $\mathrm{X}$ & M, LA \\
\hline Publication & & $\mathrm{X}$ & $\mathrm{X}$ & $\mathrm{X}$ & $\mathrm{X}$ & $\mathrm{M}$ & & $\mathrm{X}$ & $\mathrm{X}$ & $\mathrm{X}$ & $\mathrm{M}$ \\
\hline $\begin{array}{l}\text { Website, } \\
\text { Application }\end{array}$ & & $\mathrm{X}$ & $\mathrm{X}$ & $\mathrm{X}$ & $\mathrm{X}$ & $\mathrm{M}$ & & $\mathrm{X}$ & $\mathrm{X}$ & $\mathrm{X}$ & $\mathrm{M}$ \\
\hline Social media & & & & $\mathrm{X}$ & $\mathrm{X}$ & $\mathrm{M}$ & & $\mathrm{X}$ & $\mathrm{X}$ & $\mathrm{X}$ & LA, M \\
\hline Film & & & & $\mathrm{X}$ & & $\mathrm{M}$ & & $\mathrm{X}$ & $\mathrm{X}$ & & M, LA \\
\hline Image building & $\mathrm{X}$ & & $\mathrm{X}$ & $\mathrm{X}$ & & M, LA & & $\mathrm{X}$ & $\mathrm{X}$ & $\mathrm{X}$ & M, LA \\
\hline Forum, workshop & $\mathrm{X}$ & & $\mathrm{X}$ & & $\mathrm{X}$ & M, LA & & $\mathrm{X}$ & $\mathrm{X}$ & & LA, M \\
\hline
\end{tabular}




\begin{tabular}{|c|c|c|c|c|c|c|c|c|c|c|c|}
\hline \multirow{2}{*}{$\begin{array}{l}\text { Success factors } \\
\text { for public } \\
\text { involvement }\end{array}$} & \multirow[t]{2}{*}{$\begin{array}{c}\text { Expert: } \\
\text { LA }^{1}\end{array}$} & \multicolumn{5}{|c|}{$\begin{array}{c}\text { Establishment of Blessed } \\
\text { Sándor István Park }\end{array}$} & \multicolumn{5}{|c|}{$\begin{array}{c}\text { Revitalization of Holdudvar } \\
\text { Park }\end{array}$} \\
\hline & & $\mathbf{A}^{2}$ & $\mathbf{B}^{3}$ & $\mathrm{C}^{4}$ & $D^{5}$ & $\mathbf{M} / \mathbf{L A}^{6}$ & $\mathbf{A}^{2}$ & $\mathbf{B}^{3}$ & $\mathrm{C}^{4}$ & $D^{5}$ & M/LA ${ }^{6}$ \\
\hline \multicolumn{12}{|l|}{ Organization } \\
\hline \multicolumn{12}{|l|}{$\begin{array}{l}\text { Bringing local } \\
\text { forces together }\end{array}$} \\
\hline \multicolumn{12}{|l|}{$\begin{array}{l}\text { Local project } \\
\text { office }\end{array}$} \\
\hline \multicolumn{12}{|l|}{ Local cooperation } \\
\hline \multicolumn{12}{|l|}{$\begin{array}{l}\text { Setting up an } \\
\text { association }\end{array}$} \\
\hline Community rules & $\mathrm{X}$ & & & $\mathrm{X}$ & & M, LA & & $\mathrm{X}$ & $\mathrm{X}$ & & M, LA \\
\hline $\begin{array}{l}\text { Involvement of } \\
\text { external experts }\end{array}$ & & & & & $\mathrm{X}$ & M & & $\mathrm{X}$ & $\mathrm{X}$ & & LA, M \\
\hline \multicolumn{12}{|l|}{ Making plan } \\
\hline $\begin{array}{l}\text { Use of existing } \\
\text { knowledge }\end{array}$ & $\mathrm{X}$ & & $\mathrm{X}$ & & & LA, M & & $\mathrm{X}$ & & & LA, M \\
\hline Needs assessment & $\mathrm{X}$ & $\mathrm{X}$ & $\mathrm{X}$ & & $\mathrm{X}$ & M, LA & & $\mathrm{X}$ & $\mathrm{X}$ & $\mathrm{X}$ & LA, M \\
\hline $\begin{array}{l}\text { Residents' ideas } \\
\text { competition }\end{array}$ & $\mathrm{X}$ & & & & & & & & & & \\
\hline $\begin{array}{l}\text { Design } \\
\text { competition }\end{array}$ & $\mathrm{X}$ & & & & & & & & & & \\
\hline $\begin{array}{l}\text { On-site planning } \\
\text { opportunity }\end{array}$ & $\mathrm{X}$ & & $\mathrm{X}$ & & & M, LA & & $\mathrm{X}$ & & & LA, M \\
\hline Poll & $\mathrm{X}$ & & & & & & & $\mathrm{X}$ & $\mathrm{X}$ & & LA, M \\
\hline $\begin{array}{l}\text { Community } \\
\text { involvement }\end{array}$ & $\mathrm{X}$ & & $\mathrm{X}$ & & $\mathrm{X}$ & M, LA & & $\mathrm{X}$ & $\mathrm{X}$ & $\mathrm{X}$ & LA, M \\
\hline \multicolumn{12}{|l|}{ Action } \\
\hline Testing, modelling & $\mathrm{X}$ & & & & & & & & & & \\
\hline $\begin{array}{l}\text { Community } \\
\text { implementation }\end{array}$ & $\mathrm{X}$ & & & $\mathrm{X}$ & $\mathrm{X}$ & M & & & $\mathrm{X}$ & & M \\
\hline Sports events & & & & & $\mathrm{X}$ & M & & & & & \\
\hline Art events & & & & & & & & & $\mathrm{X}$ & & M \\
\hline Community events & & & & $\mathrm{X}$ & $\mathrm{X}$ & $\mathrm{M}$ & & $\mathrm{X}$ & $\mathrm{X}$ & $\mathrm{X}$ & M, LA \\
\hline Mobile equipment & $\mathrm{X}$ & & & & & & & & & & \\
\hline Message boards & $\mathrm{X}$ & & & & & & & & & & \\
\hline \multicolumn{12}{|l|}{ Programme } \\
\hline Urban education & $\mathrm{X}$ & & & & & & & & & & \\
\hline $\begin{array}{l}\text { Community/social } \\
\text { programmes }\end{array}$ & & & & & $\mathrm{X}$ & M & & & $\mathrm{X}$ & & M \\
\hline
\end{tabular}




\begin{tabular}{|c|c|c|c|c|c|c|c|c|c|c|c|}
\hline \multirow{2}{*}{$\begin{array}{l}\text { Success factors } \\
\text { for public } \\
\text { involvement }\end{array}$} & \multirow[t]{2}{*}{$\begin{array}{l}\text { Expert: } \\
\text { LA }^{1}\end{array}$} & \multicolumn{5}{|c|}{$\begin{array}{l}\text { Establishment of Blessed } \\
\text { Sándor István Park }\end{array}$} & \multicolumn{5}{|c|}{$\begin{array}{c}\text { Revitalization of Holdudvar } \\
\text { Park }\end{array}$} \\
\hline & & $\mathbf{A}^{2}$ & $\mathbf{B}^{3}$ & $\mathrm{C}^{4}$ & $D^{5}$ & $\mathbf{M} / \mathbf{L A}^{6}$ & $A^{2}$ & $\mathbf{B}^{3}$ & $\mathrm{C}^{4}$ & $D^{5}$ & M/LA ${ }^{6}$ \\
\hline $\begin{array}{l}\text { Cultural } \\
\text { programmes }\end{array}$ & & & & & $\mathrm{X}$ & $\mathrm{M}$ & & & $X$ & $\mathrm{X}$ & $\mathrm{M}$ \\
\hline $\begin{array}{l}\text { Environmental } \\
\text { programmes }\end{array}$ & & & & & & & & & $X$ & & M \\
\hline $\begin{array}{l}\text { Local history } \\
\text { programmes }\end{array}$ & & & & & & & & & $\mathrm{X}$ & & M \\
\hline $\begin{array}{l}\text { Urban } \\
\text { regeneration } \\
\text { programmes }\end{array}$ & $\mathrm{X}$ & & & & & & & & & & \\
\hline
\end{tabular}

Notes: ${ }^{1}$ The birth of the project. ${ }^{2}$ Planning. ${ }^{3}$ Implementation. ${ }^{4}$ Afterlife. ${ }^{5}$ Tasks (factors) in which the landscape architect should be involved as an expert. ${ }^{6}$ Tasks which the landscape architect and/or the municipality actually handled.

The synthesis of the case studies is presented in Table 2, which includes the tools ${ }^{3}$ used in the public involvement process for both projects and the landscape architectural tasks that can be compared with the actual tasks performed by the landscape architect and the municipality (where the list of actors also indicates a kind of hierarchy of the extent of the involvement). In the case of Blessed Sándor István Park, option 1 was applied, while in the case of Holdudvar Park option 3 was implemented, except for certain project phases that were now in the hands of the municipality.

It is clear from the case studies that the municipality has a crucial role to play in an involvement process, as it represents stability compared to a designer and has an overview of the process, which also provides security for the residents. The whole life cycle of a project can span a long period of time, as it can take years from planning to obtaining the necessary funding for development, and the afterlife is not a phase that can be closed. As a consequence, information about the project may be lost in the case of multiple actors (where there is no secure backing from the municipality), and the time and energy invested in public involvement in the project is wasted as residents will again (or still) be sceptical if they do not receive adequate answers. A good example of this is that in the case of Holdudvar Park the social media site was set up by Újirány Landscape Architects Ltd, but after the community planning was completed, it was no longer updated, and so ÓBUD Ltd had to take over its operation because the residents involved in the planning kept track of it and communicated through it. There was also a setback when, following

3 The tools of public involvement are limitless, but they can be grouped by their nature. In a previous study, when we were trying to make the processes and opportunities for public involvement more tangible for city leaders, we grouped the tools into five categories and called them success factors, suggesting that the success of a project often depends on participation [21]. 
the completion of Holdudvar Park, a set of house rules - very important for the use of the park - was drawn up in a community planning session with the residents, but it was the designers who were aware of the background of these rules, who were otherwise not involved in the event, as they had not been given a mandate.

In the case of Blessed Sándor István Park, the experience was that having a team of different experts coordinating the process throughout had several advantages: fewer communication problems (e.g. something was said at the community planning session but nobody kept track of it); the involvement tools could be used as needed in all planning phases of the project, without having to re-engage the designer each time; the communication experts used everyday language rather than technical jargon, making the designs more understandable to the layman. It was a particular advantage for this project that a local representative was involved in the process and, knowing the community, was able to represent their interests and guide the designer's ideas in the right direction.

\section{Conclusions}

The concept of inclusion represents a shift in approach to the concept of inclusive local government. It conveys the view that there is a need for a continuous and consciously operated municipal-social framework that encourages action, cooperation, and joint thinking in the community, with the community, and for the community [22]. This call for municipalities is in line with the lessons learned from our case study that municipalities need to take on a greater role in public involvement and be good stewards of green spaces by engaging more experts. Experience shows that a project and the associated involvement processes take so long that if no one in the municipality understands and manages the project, information is lost, residents can develop mistrust, and the process can fail [9]. And trust is essential because if you have it and it increases, then public involvement tools will reach more people and be more effective, which will also have an impact on the quality and sustainability of UGI developments [1, 23].

\section{Acknowledgements}

We would like to thank our families, who supported us with free time, the team of the TÉR_KÖZ programme of the City of Budapest, the staff of the ÓbudaBékásmegyer Urban Development Ltd, and our spontaneously formed research group Next at the university, who helped us with information and encouragement. 


\section{References}

[1] Directorate-General for Research and Innovation (European Commission) - Dumitru, A., Wendling, L. (2021), Evaluating the impact of nature-based solutions: Appendix of methods. DOI: 10.2777/11361.

[2] Millennium Ecosystem Assessment (2007), Linkages between ecosystem services and human well-being. GRID-Arendal.

[3] Kovács, E., Pataki, Gy., Kelemen E., Kalóczkai, Á. (2011), Az ökoszisztéma szolgáltatások fogalma a társadalomkutató szemszögéből. Magyar Tudomány $2011 / 7$.

[4] LED (2021), Strategic partnership landscape education for democracy. Ledwiki. Available at: https://ledwiki.hfwu.de/index.php?title=Strategic_Partnership_ Landscape_Education_for_Democracy.

[5] Makhzoumi, J., Egoz, S., Pungetti, G. (2011), The right to Landscape: Contesting landscape and human rights. Ashgate Publishing Ltd.

[6] Ruggeri, D. (2019), The what, why and how of landscape education for democracy. IN_BO 2019/4. University of Bologna, Landscape Education for Democracy.

[7] European Comission (2001), Public participation - Aarhus - Environment European Commission.

[8] Benedict, M., McMahon, E., Fund, T., Bergen, L. (2006), Green infrastructure: Linking landscapes and communities. Bibliovault OAI Repository, the University of Chicago Press.

[9] Lukácsházi, G. (2021), Önkormányzatok társadalmi bevonási lehetőségeinek és konkrét esettanulmányoknak a bemutatása - interjú.

[10] TÉR_KÖZ web (2021), TÉR_KÖZ - Térköz pályázat.

[11] Kocsis, J., Csanádi, G. (2018), Kutatási jelentés - Helyi településfejlesztési fókuszú közszolgáltatások inkluzív faktorainak azonosítását célzó kutatás.

[12] Számadó, R. (2014), Inkluzív önkormányzat. Budapest.

[13] Miklós, I., Judit, T. N., Róza, S. (2019), 21. századi önkormányzati sikertényezók vizsgálata az ÖFFK II. projekt kutatásainak tükrében 141.

[14] Kocsis, J., Csanádi, G., Polyák, T., Mező, J., Nothart, P., Simon, M., Szapu, J. S. (2018), Ajánlások - Az inkluzív településmenedzsment megvalósításához. Budapest: KÖFOP-2.3.4-VEKOP-15-2016-00002 „Önkormányzati Fejlesztések Figyelemmel Kísérése II.".

[15] Sain, M. (2010), Területfejlesztési füzetek 1. - Segédlet a közösségi tervezéshez.

[16] Juhász, G. A. (2018), A közösségi tervezés szerepe a városfejlesztésben a fôvárosi TÉR-KÖZ pályázat példáján. Thesis (Corvinus University of Budapest - Department of Social Sciences and International Relations).

[17] Keresztes-Sipos, A., Fekete, A., Balogh, P. I. (2021), A case study on the potential of public involvement in green space development reflecting to 
Arnstein's ladder of citizen participation. $6^{\text {th }}$ Conference on Horticulture and Landscape Architecture in Transylvania.

[18] Dömötör, T. (2009), Közösségi részvétel a területi tervezésben. $\mathrm{PhD}$ thesis (Corvinus University of Budapest).

[19] Budapest Fôváros Főpolgármesteri Hivatal (2019), A fôvárosi TÉR_KÖZ városrehabilitációs pályázat 2013 és 2019 közötti eredményei. Budapest Főváros Önkormányzata.

[20] Tervezői szerződés (2015), Tervezói szerzôdés a Holdudvar park revitalizációjának tájépítészeti tervezéséhez.

[21] Horváth, D., Keresztes-Sipos, A., Lukácsházi, G., Avar, Z., Virág, D. B., Hámori, P. (2018), TÉR_KÖZ Budapest Navigátor: Kézikönyv a társadalmi bevonáshoz. Budapest: Budapest Főváros Főpolgármesteri Hivatal.

[22] Számadó, R. (2018), Inkluzív önkormányzat-építés. Budapest.

[23] Pleasant, M. M., Gray, S. A., Lepczyk, C., Fernandes, A., Hunter, N., Ford, D. (2014), Managing cultural ecosystem services. Ecosystem Services 8, 141-147. 